América sin Nombre, n. 24 (2020): 91-100

DOI 10.14198/AMESN.2020.24-2.08

ISSN: 1577.3442 / eISSN: 1989-9831

Fecha de recepción: 18/02/2019

Fecha de aceptación: 26/02/2019
Modo de citación de este artículo:

Sandoval Caballero, Rosalía. "Diferencias de la vista en las Soledades y El sueño». La nueva novela latinoamericana sin límites. Lise Segas y Félix Terrones (coordinadores). América sin Nombre, 24 (2020): 91-100, DOI: 10.14198/AMESN.2020.24-2.08

Link para este artículo: http://dx.doi.org/10.14198/AMESN.2020.24-2.08

\title{
Diferencias de la vista en las Soledades y El sueño
}

\author{
Differences of sight in Soledades and El sueño
}

\author{
Rosalía Sandoval Caballero* \\ Universidad de Oviedo
}

\section{Resumen}

El motivo de la vista es capital para comprender la composición de Elsueño. En las Soledades, este sentido también destaca en el recorrido del peregrino, pero sus connotaciones y desarrollo son muy otros, pues la visión que predomina en la travesía del alma tiene un acentuado carácter intelectual y guarda un estrecho vínculo con la representación imaginaria, presente en la exposición misma de su argumento; mientras que las evocaciones visuales, en la silva de Góngora, corresponden sobre todo a la experiencia sensible. Este artículo analiza el tipo de vista (sensible e intelectual) que prevalece en dichas obras, así como el modo en que esta incide en sus principales diferencias de contenido.

Palabras clave: Soledades, El sueño, vista, Sor Juana Inés de la Cruz, Luis de Góngora, siglo XviI.

\section{Abstract}

The relevance of sight in Sor Juana's El sueño is the capital to understand its composition. In Góngora's Soledades this sense also stands out in the journey of the pilgrim, but its connotations and development are very different, because the vision that predominates in the journey of the soul has an accentuated intellectual character and keeps a close link with the imaginary representation, present in the very exposition of his argument; while the visual evocations, in the silva of Góngora, correspond above all to the sensible experience. This article analyzes the type of sight (sensitive and intellectual) that prevails in these works, as well as the way in which this affects its main content differences.

Keywords: Soledades, El sueño, sight, Sor Juana Inés de la Cruz, Luis de Góngora, seventeenth century.

Uno de los asuntos que más ha sido atendido por la crítica sorjuanina es la cercanía estilística con Luis de Góngora; interés motivado por el epígrafe con el que la silva de la poeta novohispana apareció publicada en 1692: «Primero Sueño, que así intituló y compuso la madre Juana Inés de la Cruz, imitando a Góngora» (247). Si bien la correlación implícita de ese título también remite a las Soledades, es posible que este no haya sido el elegido por su autora. De cualquier forma, la vinculación entre estos poetas

\footnotetext{
* Doctora en Filología Hispánica por la Universidad de Oviedo. Actualmente, se desempeńa como becaria del Servicio de Biblioteca, Documentación y Archivo de la Junta General del Principado de Asturias. Ha realizado diversos trabajos de investigación, impartido conferencias en el Archivo de Indianos de Colombres y en la Universidad Veracruzana, así como talleres sobre literatura barroca en la Biblioteca del Instituto de Artes Gráficas de Oaxaca.
} 
está justificada por la estructura métrica que comparten sus respectivas obras maestras y por el empleo que Sor Juana hace de recursos característicos de la poesía gongorina -abundantes hipérbatos, cultismos, perífrasis y conceptos-, todo ello fundamento de aquel epígrafe ${ }^{1}$. Sin embargo, pese a que la filigrana verbal que Sor Juana emula en su silva sea gongorina, esto no significa que tenga las mismas intenciones ni el mismo programa poético. Por ello, queremos concentrarnos en las divergencias que subyacen en el tipo de vista que prevalece en estas obras, así como en el modo en que esta incide en sus diferencias de contenido.

Esta vía de análisis ha sido poco recurrente, pues el enfoque estilístico ha predominado en los estudios comparativos que se han realizado sobre estas $\mathrm{obras}^{2}$; sin que se haya puesto una mayor atención a la distancia que existe en los temas elegidos por cada autor. Si bien el estudio de los aspectos visuales en las descripciones del poeta andaluz es un lugar común en la crítica sobre las Soledades y en general de la literatura barroca, de manera concreta, el motivo de la vista no ha sido utilizado para distinguir los temas que vertebran esta silva de los que integran El sueño, cuyo estudio de lo visual ha sido bastante menos atendido ${ }^{3}$ y tampoco había sido empleado para destacar el carácter intelectual de los asuntos por los que discurre.

A grandes rasgos, la vista del alma aludida por Sor Juana tiene como trasfondo la contemplatio y la representación de la que es protagonista y espectadora, "la suprema de lo sublunar», corresponde a la actividad imaginaria. El ojo con el que mira el alma es el de la fantasía, mientras que el peregrino observa con los ojos del cuerpo todos aquellos paisajes, animales, personas, etcétera, que habitan los diferentes escenarios que pueblan su recorrido. De manera que en la trama misma de estas silvas subyace una clara

1. Existe una edición conjunta de ambos poemas realizada por Antonio Carreira y Antonio Alatorre (Góngora 2009).

2. Mencionamos parte de la bibliografía más destacada al respecto: (Gates 1939; Carilla 1946; Méndez Plancarte 1951; Perelmuter 1982; Sánchez Robayna 1991; Rivers 1996; Roses 2010).

3. En mi tesis doctoral (2018), que próximamente será publicada, profundizo en la visualidad de El sueño a partir de un estudio detallado del vínculo entre el motivo de la vista y el planteamiento de los límites del intelecto, el trasfondo teórico visual involucrado en la formulación metafórica del sueño y el contexto cultural en el que se inscribe su planteamiento. distinción en el tipo de vista que es aludido al referir el respectivo viaje de sus protagonistas.

Conviene tener en cuenta que a partir de la invención de la perspectiva en el siglo xv la experiencia visual comenzó a cobrar una relevancia inusitada, pues esta técnica de representación pictórica contiene una importante base óptica -de ahí que la teoría de la visión de Alhacén tenga un papel tan destacado en sus fundamentos teóricos (Belting 8) - y su desarrollo se encuentre en el origen del protagonismo que lo visual adquiriría durante la revolución cultural de los siglos XV-XVII. A lo largo de estos siglos el tratamiento de la visión sufrió considerables variaciones, de una representación «naturalista» capaz de representar las cosas del mundo con una notable fidelidad, donde la perspectiva dominaba la escena pictórica sobre todo del primer Renacimiento, se pasó a la alteración de lo visible, al empleo de más de un punto de fuga y al uso de artificios como la anamorfosis. Asimismo, durante la Contrarreforma el acto de ver fue incorporado como tema para evocar la experiencia espiritual en los llamados cuadros de visión ${ }^{4}$. En esas centurias también tuvo lugar el auge de la cartografía, la invención de instrumentos ópticos (el telescopio y el microscopio), así como de la linterna mágica y el perfeccionamiento del mecanismo de la cámara oscura, utilizada por algunos pintores como Vermeer ${ }^{5}$. Todo ello es parte del contexto en el que se inscriben las obras que nos ocupan, aunque por supuesto solo se trata de algunos datos generales que pueden ayudar a situarnos en su tiempo.

Tanto en la travesía del protagonista de las Soledades como en la de El sueño, el motivo de la vista es inherente a su narración, pero sus implicaciones son muy distintas. La vista es un motivo que aparece de manera explícita en El sueño y es capital para comprender su composición; en Soledades este sentido también destaca en el recorrido del peregrino, pero sus connotaciones y desarrollo son muy otros, pues en Sor Juana tiene un trasfondo filosófico y teológico, además la referencia a la vista del alma es en sí misma metafórica y es evocada mediante figuraciones ópticas (el espejo del Faro de Alejandría y la linterna mágica), dado que este sentido ha sido considerado, desde los orígenes de la filosofía occidental, el más

4. Un análisis detallado sobre los cuadros de visión puede consultarse en (Stoichita 1996).

5. Sobre el uso que hicieron los pintores de la cámara oscura, el libro de Svetlana Alpers (1987) es uno de los estudios de referencia, en años más recientes Snyder (2017) realizó un interesante acercamiento al trabajo de Vermeer y Leeuwenhoek. 
apto para el estudio del ámbito inteligible. Por su parte, la vivacidad descriptiva de Góngora entronca con el deleite visual de su protagonista, suscitado por el descubrimiento de aquel mundo campestre. En síntesis, las diferencias temáticas entre ambos poemas afectan de manera decisiva su tratamiento de lo visual y viceversa, lo cual es patente en el desarrollo que ese motivo tiene en sus respectivas tramas, por eso es pertinente comenzar distinguiendo sus asuntos.

\section{Diferencias temáticas}

El argumento de las Soledades y El sueño no puede ser más distinto, como en cierto modo lo advirtió Diego Calleja en su «Aprobación» al volumen Fama y obras póstumas del Fénix de México (1700), aunque sin entrar en detalles sobre las materias desarrolladas en uno y otro poema. En su comentario, Calleja solo destaca la naturaleza tan árida de las materias elegidas por Sor Juana e indica lo ajeno que resulta al numen poético que se hable de «los principios, medios y fines con que se cuece en el estómago el manjar, hasta hacerse substancia del alimento» (25), así como "lo que pasa en las especies sensibles, desde el sentido externo al común, al entendimiento agente, a ser intelección» (25). De ahí que atribuya su dificultad a la hondura de sus asuntos (26) y con ello ponga en relieve la diferencia más evidente entre estas silvas.

Por el contrario, la sencillez del trasfondo narrativo de las Soledades, sus referencias al mundo rural y la presencia de términos cotidianos de la vida rústica es una de las principales causas del ataque de Juan de Jáuregui, pues como ha indicado Robert Jammes en su libro La obra poética de don Luis de Góngora y Argote: "Jáuregui reafirma que no es hostil a la oscuridad, con tal que el tema sea digno de la dificultad así creada» (527) y al analizar las razones de fondo que avivaron la controversia sobre la silva de Góngora, el crítico francés concluye:

Haber consagrado al mundo rural contemporáneo un gran poema escrito en verso noble y de tono constantemente elevado, es lo que hace de las Soledades un poema revolucionario; $y$, en fin de cuentas, fue eso lo que provocó las interminables discusiones en torno a ellas, incluso si, aparentemente, la "polémica del cultismo» tuvo por objeto cuestiones de estilo (521).

Si el humilde contenido de las Soledades adquiere una acentuada novedad por haber sido escrito en una forma sublime (Carreira 226), el de El sueño puede considerarse insólito para la poesía, al estar nutrido de un material teórico erudito y muy poco explorado por la lírica. De manera que sus peculiaridades temáticas son a todas luces contrarias.

Así, el carácter inmaterial del alma -protagonista de aquel sueńo que tiene lugar en la silva de Sor Juana, cuyo propósito es ver y comprender toda la creación con sus «intelectuales bellos ojos» $(\mathrm{v} .441)^{6}$, que son deslumbrados por el «objeto que excede en excelencia / las líneas visuales» (vv. 458-459)-, de entrada marca una acusada diferencia con el recorrido del peregrino, del que sabemos es joven, noble y padece mal de amores; arrojado por la tormenta a una playa desierta comienza sus andanzas en las que se recreará con los paisajes, la hospitalidad de las personas que irá conociendo, con lo que le cuenten y observe de aquel mundo rural que le era desconocido. El forastero es espectador de todo aquello que se relata, al igual que el alma, pero pese a ser testigo y agente de su travesía, esta no es capaz de entender ni ver lo que quiere, al toparse con las limitaciones intrínsecas a su naturaleza, mientras que el muchacho mira todo lo que se le ofrece al paso. En cuanto a su estructura, baste por ahora decir que el recorrido del extranjero transcurre en cinco días y el del alma en una noche, tomando en cuenta que la silva de Góngora está claramente inacabada, no así la de Sor Juana.

Los temas de estas silvas afectan de manera decisiva su desarrollo narrativo; esto es evidente en las prosificaciones que varios críticos han realizado con la finalidad de facilitar su acercamiento -recurso sin duda valiosísimo para sortear sus escollos léxicos y sintácticos, iniciarse en su estudio y conocer de manera general su marco narrativo- y explica el hecho de que podamos ubicarnos más rápido en el recorrido del peregrino con la excelente prosificación de Robert Jammes de Soledades, en buena medida, gracias a la "trama novelesca» que subyace en el poema de Góngora ${ }^{7}$, no así en la travesía del

6. Utilizo la edición de El sueño de Alfonso Méndez Plancarte (Cruz, Obras completas 335-359). No obstante, también puede consultarse la edición de Alberto Pérez Amador Adam, El precipicio de Faetón: edición y comento de Primero Sueño de Sor Juana Inés de la Cruz (2015) y la más reciente de Martha Lilia Tenorio que forma parte del libro Ecos de mi pluma. Antología en prosa y verso (2018).

7. Con un espléndido resumen de las Soledades, Jammes muestra «la importancia del contenido narrativo del poema, su variedad y su precisión» («Introducción» 35-36). Así, como 
alma contenida en Elsueño, pues acceder a su estructura narrativa es más complicado, incluso provistos con la destacada prosificación de Alfonso Méndez Plancarte, dado que sus entresijos teóricos están tan unidos a la secuencia del recorrido que plantea que los referentes de su narración, conforme el poema avanza, quedan muy ocultos por las referencias previas que deben haber sido descifradas y esto es uno de los aspectos que más dificulta la comprensión de su argumento.

Todo esto nos lleva a reiterar la singularidad de dichas obras y nos permite comprender el sentido que en el Barroco tiene el término de imitación, pues imitar no significa copiar sin más, sino reinventar y ese es uno de los méritos más notables de la poeta novohispana, haber creado algo propio e inusitado a partir de un material tan sugestivo y complejo ${ }^{8}$. Pese a que los dos poemas narren el viaje de su protagonista, su naturaleza es muy distinta, como distinto es el papel que desempeña la vista en su recorrido.

\section{La vista intelectual del alma}

Los problemas por los que discurre El sueño tales como las limitaciones del entendimiento humano, en su incapacidad de comprender toda la creación,

las razones que permitieron hablar a Dámaso Alonso de una "trama novelesca» en sus Estudios y Ensayos gongorinos y a otros estudiosos como María Rosa Lida profundizar en este asunto. Asimismo, Jammes puntualiza que la interpretación alegórica de Soledades no es clara —como sí lo es en El sueño-, pues esta "corresponde sin duda al deseo de dar un alcance más o menos filosófico al poema, para responder a las críticas de los impugnadores que encontraban el asunto demasiado humilde; pero es poco convincente: no se ve claramente en qué las ocupaciones descritas en la segunda Soledad corresponderían mejor a la "adolescencia" que las de la tercera» $(46-47)$.

8. La reinvención es el rasgo que Mercedes Blanco destaca de la imitatio: «La estética del ingenio se traduce en la poesía barroca por una práctica de la lectura y por lo tanto de la imitatio orientada por la intuición de lo agudo, de lo conceptuoso. Lo que se aísla, se registra y se imita son los conceptos de los poetas y escritores clásicos o modernos. Imitarlos es "acomodarlos" a otra ocasión, lo que viene a ser lo mismo que reinventarlos; esta reinvención potencia su agudeza, su carácter paradójico e hiperbólico" (Góngora o la invención de una lengua 37). Y Aurora Egido, en su libro Fronteras de la poesía en el barroco, nos recuerda que «La novedad en la creación de géneros y estilos venía apoyada por la inventio barroca que iba quitando terreno a la teoría de la imitación renacentista» (28). el proceso mediante el cual la fantasía forma sus imágenes interiores y la manera en la que se articulan las representaciones que el alma contempla para iniciar su travesía especulativa son de una considerable envergadura teórica y por tanto muy difíciles de poetizar. De ahí que en el planteamiento de dichos asuntos es donde radica su auténtico prosaísmo y en su alusión metafórica su máxima complejidad, pues durante el sueńo del alma los aspectos referidos son sumamente abstractos, ya que en él se emula el proceso reflexivo de «la reina de lo sublunar», su ascenso contemplativo, su imposibilidad de ver y comprender todo lo creado, tanto de manera general como a partir de cada una de las cosas que conforman la creación. De manera que el recorrido contemplativo del alma es lo que está contenido en aquel sueño y por eso sus alusiones a la vista están asociadas con aquel proceso intelectual, además sus versos contienen una referencia explícita a la formación de las imágenes del sueño ahí representado (vv. 253-291).

Sobre el empleo que Sor Juana hace del concepto - el rasgo más característico de la lengua poética del cordobés 9 - también hay notables divergencias; dado que en ella son más dilatados ${ }^{10} \mathrm{y}$ por tanto su identificación más trabajosa, aunque menos abundantes. La mejor muestra de ello es la correlación entre la fantasía, el faro y la linterna mágica, los cuales articulan la formulación metafórica del sueño del alma. Precisamente, el primer obstáculo para identificar su vínculo - y con ello la relación inédita, paradójica y, en definitiva, conceptuosa de la que forman parte- es la distancia que media entre sus descripciones, sobre todo entre la fantasía (vv. 281-291) y la linterna mágica (vv. 873-886), pues la del faro aparece muy cerca de la correspondiente a la fantasía (vv. 266-280). No obstante, la mayor dificultad para advertir su conexión subyace en su trasfondo teórico, que hunde sus raíces en las teorías proyeccionistas de la visión y en la alusión a la pintura como sombra en oposición al tipo de representación de la fantasía.

En pocas palabras, Sor Juana describe fenómenos visibles para referirse a fenómenos invisibles, por ejemplo, el modo en que la fantasía forma «de mentales sin luz, siempre vistosas / colores las figuras

9. Este aspecto ha sido estudiado por varios críticos tales como Jammes, «Introducción» 120; Carreira 45 y Blanco, Góngora o la invención de una lengua 79.

10. De cierto modo, Martha Lilia Tenorio, en su libro El gongorismo en Nueva España, indica esta característica del concepto en Sor Juana, al mencionar que en El sueño «no alcanza la concisión conceptual de Góngora» (174). 
[...]» (vv. 284-285) tanto de las criaturas sublunares como de "[...] aquellas / que intelectuales claras son estrellas» (vv. 287-288) es evocado mediante la descripción del proceso reflexivo y proyectivo del faro (vv. 266-280). Incluso una referencia tan material como la relativa al proceso de alimentación del cuerpo es utilizada para aludir a la formación del pneuma psíquico que posibilita la actividad contemplativa del alma, cuyo ascenso es evocado con el vuelo de un águila que quiere colocar su nido entre los rayos del sol (vv. 330-338).

La importancia que en estos asuntos tiene la tradición teológica cristiana es otro de los aspectos que más la alejan de las Soledades, ya que la silva de Góngora carece de una notable presencia de referencias a la religión católica, ni siquiera al relatar una boda de labradores en la primera Soledad, donde más bien nos encontramos es «una ceremonia muy pagana que transporta súbitamente al lector al universo greco-romano de los poemas mitológicos: un coro de muchachos alterna con otro de muchachas para invocar al dios Himeneo» (Jammes, La obra poética de don Luis de Góngora y Argote 502).

Menos abstracto es el inicio y el final de El sueño, la noche y el amanecer que enmarcan la travesía del alma ${ }^{11}$, lo cual explica su mayor similitud con el tipo de descripciones contenidas en las Soledades -sobre todo las relativas a las aves nocturnas y la llegada del alba-, similitud que no solo se basa en las perífrasis mitológicas utilizadas, sino en los referentes que en primera instancia evoca, pues las cosas, experiencias y sucesos a los que Góngora se refiere corresponden a lo concreto y mundano.

\section{La vista sensible del peregrino}

Las Soledades nos hace partícipes del asombro, deleite y descubrimientos experimentados por su protagonista, ante un mundo que parece recién nacido. A través de su mirada somos testigos de un viaje por la

11. Aunque conviene señalar que estos pasajes no están desprovistos de connotaciones teóricas y simbólicas, y su comprensión depende en igual medida del entendimiento del conjunto. Por ejemplo, las referencias a las aves nocturnas (la lechuza, los murciélagos y el búho) tienen una vinculación simbólica con la visión, así como el modo en que la luz va repartiendo a las cosas visibles sus colores y restituyendo los sentidos exteriores es comprensible a cabalidad solo a partir del entendimiento de la importancia que tienen en el sueño los sentidos interiores. sencillez cotidiana de la vida campestre que estimula la memoria visual y lectora, la agudeza, el ingenio, en definitiva, el intelecto.

Entre las escenas ahí narradas se encuentra la cena del peregrino con unos cabreros, el baile y canto de unas serranas, el desfile de montańeses rumbo a una boda de labradores, las competiciones de carreras, salto y lucha de los asistentes a aquella ceremonia, la pesca de ostiones, lenguados, congrios, salmones, robalos, focas..., aves de presa cazando, etcétera. Asimismo, son prolijas las descripciones de alimentos, animales, plantas, utensilios y paisajes. Pero su signo de identidad no solo radica en lo que evoca, pese a que su asunto sea de una notable novedad (Carreira 229), sino también en la forma en que lo hace, pues las imágenes de Góngora exploran las cualidades más distintivas de las cosas, su forma, sonido, color y textura. En este sentido, su mirada se asemeja a la del pintor -si asumimos como menciona Leon Battista Alberti que «el pintor se empeña en imitar sólo las cosas que se ven a la luz» (69)-, es decir, la correlación que se puede establecer entre la poesía de las Soledades y este arte corresponde a una pintura sumamente descriptiva ${ }^{12}$.

No obstante, la experiencia visual provocada de forma verbal es muy diferente a la confrontación directa con un cuadro, diríase incluso que son fenómenos si no opuestos, muy distintos, pues nos sitúan entre lo visible y lo invisible. Aun así, la poesía de Góngora es una invitación al acto mismo de ver - pero de una peculiar visión que ejercita el intelecto- y tiene como núcleo el concepto, que el lector debe descifrar para poder visualizar aquello que evoca; pues para que el ojo de la imaginación se abra ante las imágenes de este poeta, primero hay que realizar un detenido proceso de comprensión que pone en juego nuestros conocimientos lingüísticos, sintácticos, retóricos, literarios..., al tiempo que activa el recuerdo de nuestro experiencia visual, por ejemplo, del mar, la noche, el rocío, la primavera.

La precisión descriptiva de Góngora llega a ser tan eficaz para la imaginación (la visión del intelecto)

12. Sobre las diferentes vínculos que se han establecido entre la poesía de las Soledades y la pintura puede consultarse el artículo de Mercedes Blanco «Lienzo de Flandes: las Soledades y el paisaje pictórico» (1998). Asimismo, vale la pena tomar en cuenta los inauditos logros de la pintura y su creciente aprecio en Espańa durante el reinado de Felipe III y Felipe IV, que pudieron motivar el interés de Góngora en conseguir una máxima sofisticación sintáctica, léxica y retórica de la poesía (Blanco, «Góngora et la peinture» 198). 
que su lectura es inmenso regocijo para la mente y no pocas veces nos parece tener delante aquello que esboza. Incluso Jáuregui reconoce esta peculiaridad de la silva gongorina y hace un "homenaje involuntario» (Góngora 396) a lo que Jammes llama el "realismo de las Soledades» (Jammes, La obra poética de don Luis de Góngora y Argote 505). El estudioso francés, en la nota 975 de su edición de Soledades, también indica que el autor del Antidoto, refiriéndose a la descripción de una lucha entre dos jóvenes, comenta: "parece que dos muchachos se toman a caídas y que los veo". A lo que el Abad de Rute, en el Examen del "Antídoto», responde «esta es la valentía del poeta, pintar de suerte las cosas que parezca que se ven» (Góngora 396).

Así, el Homero español nos transmite el color, la temperatura y consistencia de la leche «que exprimir vio el Alba aquel día, / mientras perdían con ella / los blancos lilios de su frente bella, / gruesa le dan y fría, / impenetrable casi a la cuchara» (I, vv. 147151); las fibras de un trozo de carne seca se nos revelan hilos purpúreos de grana fina, del que antes fue macho cabrío y ahora es cecina ${ }^{13}$; a partir del contenido que transporta una vasija de barro también nos hace observar «Lo que lloró la Aurora / (si es néctar lo que llora) / y, antes que el Sol, enjuga / la abeja que madruga / a libar flores y a chupar cristales, / en celdas de oro líquido, en panales / la orza contenía que un montañés traía (I, vv. 327-328); en sus versos, suponemos el vuelo colorido del Fénix «pájaro de Arabia, cuyo vuelo / arco es del cielo / no corvo, más tendido» (I, 462-464); descubrimos la forma exacta en que se derrite el quesillo «rubio / imitador süave de la cera» (I, vv. 874-875); advertimos uno de los rasgo más distintivos y expresivos de una mano detalle mucho más frecuente en la pintura- «rústica, vaquera, / blanca, hermosa mano, cuyas venas / la distinguieron de la leche apenas»; (I, vv. 874-876); asistimos a la pesca de un congrio «que viscosamente liso / las telas burlar quiso, / tejido en ellas se quedó burlado» (II, 93-95); admiramos el vívido curso irrigador de un arroyo por un huerto «sierpe, y sierpe al fin pisada / (aljófar vomitando fugitivo / en lugar de veneno), / torcida esconde, ya que no enroscada, /

13. «El que de cabras fue dos veces ciento / esposo casi un lustro (cuyo diente / no perdonó a racimo aun en la frente / de Baco, cuando más en su sarmiento: / triunfador siempre de celosas lides / lo coronó el Amor, mas rival tierno, / breve de barba y duro no de cuerno, / redimió con su muerte tantas vides), / servido ya en cecina, / purpúreos hilos es de grana fina» (I, vv. 153-162). las flores que de un parto dio lascivo / aura fecunda al matizado seno / del huerto, en cuyos troncos se desata / de las escamas que vistió de plata» (II, vv. 320-327); sin nombrarlo, se nos aparece el búho con su pausado vuelo "Grave de perezosas plumas globo, / que a luz lo condenó incierta la ira / del bello de la stigia Deidad robo, / desde el guante hasta el hombro a un / joven cela: / esta emulación pues de cuanto vuela / por dos topacios bellos con que mira» (II, vv. 791-796) y un prolongado etcétera ${ }^{14}$.

Góngora le da un brillo nuevo a todo lo que evoca, con tal vivacidad y exactitud que es sumo deleite para la imaginación ${ }^{15}$. De este modo, el poeta andaluz construye "experiencias visuales posibles» (Blanco, «Lienzo de Flandes: las Soledades y el paisaje pictórico» 274) y por eso las descripciones de las Soledades son más próximas a la vista sensible y en este sentido más plásticas -sin olvidar las distancias entre la representación poética y la pictórica y que dichas descripciones se realizan «a base de materiales culturales, mitológicos, simbólicos, ajenos en principio a toda reproducción empírica de las cosas»- (274); mientras que Sor Juana se concentra en representar el proceso de la visión imaginaria y sus descripciones se sitúan en un plano eminentemente intelectual.

A pesar de representar tipos de vista diferentes, la fuerza poética de estos autores coincide en el modo de estimular la imaginación, mediante sutiles elaboraciones intelectuales. Aunque debemos decir que la poesía de Elsueño también tiene el mérito de emular

14. A propósito de algunos de estos ejemplos -el de la leche, la cecina, la miel, el quesillo y de otros tantos-, Joaquín Roses analiza el proceso diacrónico de descripción que Góngora emplea para evocar el origen de aquellos alimentos, procedimiento que muestra la meditada elaboración de los pasajes que integran las Soledades no solo en lo que al espacio se refiere, sino a la importancia que tiene el tiempo en su narración, pues «En esas pequeñas historias, las materias naturales adoptan formas heroicas y son susceptibles de resumir el origen de todo un mundo» (Roses, «La descriptio diacrónica en las Soledades» 231).

15. En palabras de Mercedes Blanco: «Góngora sabe por supuesto que el poeta solamente de modo metafórico puede ser dibujante o cartógrafo. El poeta, cuyo objetivo es la energeia, la viveza ilusionista de la representación, no pretende una representación completa con informaciones cuantificadas, aunque pueda no desdeñar el efecto de realidad que procede de incluir algunas. Lo importante es menos dar instrucciones precisas para una hipotética reconstrucción de la escena o el objeto - ya sean estos reales o fabulososque estimular la memoria visual y activar la imaginación» (Góngora heroico: las «Soledades» y la tradición épica 276). 
ese proceso en su argumento y haber logrado engarzar forma y contenido en una alianza perfecta.

\section{La experiencia contemplativa y la experiencia del mundo}

Como hemos visto, la descripción de paisajes, objetos, animales, plantas, alimentos..., es una característica fundamental de las Soledades. En lo que respecta a El sueño hay que destacar su atrevida referencia poética del proceso contemplativo del alma, del pensamiento mismo, eco del «visual alado atrevimiento» (v. 368) que aquella emprende, así como sus alusiones, astronómicas, teológicas, fisiológicas y ópticas, todas ellas fruto de un saber libresco. Aunque Góngora también incluya términos técnicos en su poema, las disciplinas de estos corresponden sobre todo a la marinería, la agricultura, la pesca y la cetrería, es decir, conocimientos prácticos.

Se ha señalado la posible importancia de los viajes que Góngora realizó a Galicia, Cuenca y Ayamonte para la creación de los paisajes de las Soledades ${ }^{16}$. Por ejemplo, la exactitud de las referencias a la pesca y la caza permiten suponer que pudo conocer estas actividades de primera mano. De ahí que la vivacidad de las descripciones gongorinas probablemente provengan de la observación directa de aquellas realidades, las cuales tamiza mediante sofisticados tratamientos literarios que vuelven lo sencillo algo magnífico. Sin olvidar que la realidad es su punto de partida, pero lo que crea es "una campiña soñada», donde se trasluce una «idealización del mundo rural» (Jammes, La obra poética de don Luis de Góngora y Argote 518).

El pasaje sobre las navegaciones contenido en el discurso del "político serrano» (vv. 364-502) es uno de los más complejos, debido a los conocimientos que el lector debe tener para ser capaz de identificar aquellos lugares, sucesos y personajes que el autor solo evoca de forma perifrástica (la toma de Troya, la navegación de los Argonautas, la travesía de Colón, el enfrentamiento de los conquistadores con los indios del Caribe, la expedición de Magallanes, los descubrimientos de las islas y archipiélagos de Oceanía, entre otros) y por eso, quizá, sea el que mayor similitud tenga con la dificultad para identificar ciertos

16. Ver La obra poética de don Luis de Góngora y Argote de Robert Jammes (342-343, 486, 494-495); así como el apartado «Localización» en la introducción de su edición de Soledades (65-83). referentes de El sueño, tales como los sistemas que participan en la alimentación del cuerpo, los cuales también son descritos mediante perífrasis, aunque con la complicación añadida de alterar su orden y fragmentar su alusión, pues entre una y otra referencia median 620 versos (vv. $210-228$ y vv. 830-844).

Por su parte, los principales maestros de Sor Juana fueron sus libros, incluso al recordar, en la Respuesta a Sor Filotea de la Cruz, cuando una prelada le prohibió leer, queda claro que en sus observaciones de las cosas establecía conexiones teóricas, pues nada veía sin que le provocase una reflexión, nada veía sin segunda consideración:

Una prelada muy santa y muy cándida que creyó que el estudio era cosa de Inquisición y me mandó que no estudiase. Yo la obedecí (unos tres meses que duró el poder ella mandar) en cuanto a no tomar libro, que en cuanto a no estudiar absolutamente, como no cae debajo de mi protestad, no lo pude hacer, porque aunque no estudiaba en los libros, estudiaba en todas las cosas que Dios crió, sirviéndome ellas de letras, y de libro toda esta máquina universal. Nada veía sin refleja; nada oía sin consideración, aun en las cosas más menudas y materiales; porque como no hay criaturas, por baja que sea, en que no se conozca el me fecit Deus [«me hizo Dios»], no hay alguna que no pasme el entendimiento, si se considera como se debe. [...] Si veía una figura, estaba combinando la proporción de sus líneas y mediándola con el entendimiento y reduciéndola a otras diferentes (57).

Al relatar cómo al observar dos líneas paralelas, estas forman una aparente pirámide, se entreveran sus conocimientos geométricos y ópticos.

Paséabame algunas veces en el testero de un dormitorio nuestro (que es una pieza muy capaz) y estaba observando que siendo las líneas de sus dos lados paralelas y su techo a nivel, la vista fingía que sus líneas se inclinaban una a otra y que su techo estaba más bajo en lo distante que lo próximo: de donde infería que las líneas visuales corren rectas, pero no paralelas, sino que van a formar una figura piramidal. Y discurría si sería ésta la razón que obligó a los antiguos a dudar si el mundo era esférico o no. Porque aunque, lo parece, podía ser engaño de la vista, demostrando concavidades donde pudiera no haberlas (58).

Al observar la figura formada por el giro de un trompo suscita en ella una pregunta y extrae conclusiones mediante un sencillo experimento: 
Estaban en mi presencia dos niñas jugando con un trompo, y apenas yo vi el movimiento y la figura, cuando empecé, con esta mi locura, a considerar el fácil moto [movimiento] de la forma esférica, y cómo duraba el impulso ya impreso e independiente de su causa, bailaba el trompillo; y no contenta con esto, hice traer harina y cernerla para que, en bailando el trompo encima, se conociese si eran círculos perfectos o no los que describía con su movimiento; y hallé que no eran sino unas líneas espirales que iban perdiendo lo circular cuanto se iba remitiendo el impulso (58-59).

De la yema y la clara de un huevo saca una consideración dialéctica, lo que no sin cierta ironía llama filosofía de cocina:

¿Qué os pudiera contar, Señora, de los secretos naturales que he descubierto estando guisando? Veo que un huevo se une y fríe en la manteca o aceite y, por contrario, despedaza en el almíbar; ver que para que el azúcar se conserve fluida basta echarle una muy mínima parte de agua en que haya estado membrillo u otra fruta agria; ver que la yema y la clara de un mismo huevo son tan contrarias, que en los unos, que sirven para el azúcar, sirve cada una de por sí y juntos no (60).

Desde luego, El sueño también es muestra de sus fuertes y vehementes cogitaciones, del incesante movimiento de su imaginativa (61), al discurrir sobre el proceso imaginativo mismo, el modo en que la fantasía representa y muestra sus imágenes; donde a su vez es posible identificar una reflexión sobre el propio decir poético - me refiero al fragmento donde son descritas las funciones de la fantasía (vv. 281291)-, vinculada a la composición metafórica, pues esta figura establece una relación de semejanza entre lo desemejante, entre lo visible y lo invisible. Hannah Arendt, desde la filosofía, apunta ese carácter unificador de este tropo: «La metáfora, al salvar el abismo entre las actividades mentales interiores e invisibles y el mundo de las apariencias, fue sin duda el mejor regalo que le pudo hacer el lenguaje al pensamiento» (128). De modo que a partir de aquella que es la sustancia misma de la poesía, la poeta filósofa fue capaz de escenificar la contemplatio del alma.

Quizá, José Gaos es quien mejor advirtió ese trasfondo reflexivo contenido en la silva de Sor Juana, enlazándolo con la experiencia contemplativa que llenó sus días:

Como la vida entera de la poetisa, dormido su cuerpo, se reduce a la vida de su alma, y esta vida psíquica la sueña reducida a la pura actividad intelectual que es por excelencia la filosófica, no puede menos de pensarse que ya este preludio de la narración del sueño delata el más radical afán vital y personal de la poetisa: ser puramente intelectual y filósofa. Por lo demás, sin este afán por raíz, no tendría el sueño sentido (156).

La poeta novohispana, como excelente lectora que era, no se limitó a remedar al maestro, sino más bien, a partir de sus hallazgos pudo plasmar sus propias inquietudes. Sabido es que Góngora dotó de enorme libertad a la silva y aprovechó la flexibilidad de una forma métrica continua para hacer de este género un «taller de reflexión» poética (López Bueno 15) y en su esfuerzo por ampliar y renovar los recursos de la poesía en lengua española no solo logró una notable sofisticación técnica, sino una mayor riqueza verbal y retórica, así como una deslumbrante precisión descriptiva y una transformación en la postura misma del lector, quien deberá esmerarse en hallar los referentes del poema, que el poeta también ha urdido con empeño.

Sor Juana, a partir de las aportaciones gongorinas, supo encontrar desde la celda de un convento su propia libertad para reflexionar sobre cuestiones filosóficas, ópticas, artísticas, teológicas, etcétera, y hacer de la silva un espacio para escenificar la reflexión misma. Si Góngora logró congregar una variedad de géneros en sus Soledades, la poeta novohispana supo reunir una multiplicidad de saberes en su Sueño.

\section{Conclusiones}

En este acercamiento a las diferencias entre las Soledades y El sueño, a partir del tipo de vista (sensible e intelectual) que predomina en sus respectivos argumentos, pudimos advertir algunas claves de su composición, en la cual dicho motivo es uno de sus elementos fundamentales, al permitir aproximarnos a sus singularidades temáticas, las cuales son bastante distintas, pues mientras el poema de Góngora se sitúa en la sencillez de la vida rústica, el de Sor Juana orbita en el territorio invisible del alma. Por ello el recorrido que realizan sus protagonistas es de naturaleza muy diferente, donde las evocaciones a la vista tienen un papel crucial para advertir esta contraposición, la cual es patente en el trasfondo de las descripciones que cada uno refiere: las de Soledades dan cuenta de un ámbito concreto y mundano; por su parte, las de El sueño se colocan en un plano abstracto y suprasensible. No obstante, 
ambas silvas poseen una notable vivacidad en sus representaciones, así como un acentuado carácter intelectual en la elaboración de sus imágenes. Asimismo, es pertinente destacar que la poeta de Nepantla supo asimilar las técnicas gongorinas para lograr una máxima sofisticación poética y utilizar dichos recursos para crear una expresión propia, acorde con sus intereses contemplativos, incluso atreviéndose a reflexionar sobre el proceso imaginativo mismo en su silva. Así, la complejidad teórica de los temas por los que discurre el alma en El sueño se encuentra en el hemisferio contrario de los lugares por los que transita el peregrino de las Soledades y su observación de espectáculos y objetos, correspondientes al ámbito propiamente sensible y terreno, cifran la oposición de las experiencias visuales que estas obras describen.

\section{Bibliografía}

Alberti, Leon Battista. De la pintura y otros escritos sobre arte. Madrid: Tecnos, 1999.

Alpers, Svetlana. El arte de describir. El arte holandés en el siglo XVII. Madrid: Hermann Blume, 1987.

Arendt, Hannah. La vida del espiritu. Barcelona: Paidós, 2002.

Belting, Hans. Florencia y Bagdad. Una historia de la mirada entre oriente y occidente, Madrid: Akal, 2012.

Blanco, Mercedes. «Lienzo de Flandes: las Soledades y el paisaje pictórico». María Cruz García de Eterría y Alicia Cordón Mesa (coords.). Actas del IV Congreso Internacional de la Asociación Internacional Siglo de Oro (AISO) celebrado en Alcalá de Henares del 22 al 27 julio de 1996, Alcalá de Henares: Universidad de Alcalá, Servicio de Publicaciones, 1998: 263-274.

Blanco, Mercedes. "Góngora et la peinture». Locus Amoenus, 7, (2004): 197-208.

Blanco, Mercedes. Góngora heroico: Las «Soledades» y la tradición épica. Madrid: Centro de Estudios Europa Hispánica, 2012.

Blanco, Mercedes. Góngora o la invención de una lengua. 2a ed. rev., León: Universidad de León, 2016.

Calleja, Diego. "Aprobación del Reverendísimo Padre Diego Calleja de la compañía de Jesús». Sor Juana Inés de la Cruz. Fama y obras póstumas del Fénix de México, décima musa, poetisa americana. Madrid: Manuel Ruiz de Murga, 1700: (11-31).

Carilla, Emilio. El gongorismo en América. Buenos Aires: Facultad de Filosofía y Letras de la Universidad de Buenos Aires, 1946.
Carreira, Antonio. Gongoremas. Barcelona: Península, 1998.

Cruz, Sor Juana Inés de la. Segundo Volumen de las Obras de Sor Juana Inés de la Cruz. Sevilla: Tomás López de Haro, 1692.

Cruz, Sor Juana Inés de la. Obras completas, tomo I: Lírica personal. Alfonso Méndez Plancarte (ed.). México: Fondo de Cultura Económica, 1951.

Cruz, Sor Juana Inés de la. Carta a sor Filotea de la Cruz. México: UNAM, 2004.

Cruz, Sor Juana Inés de la. Ecos de mi pluma. Antología en prosa y verso. Martha Lilia Tenorio (ed.). México: Penguin-UNAM, 2018.

Egido, Aurora. Fronteras de la poesía en el barroco. Barcelona: Editorial Crítica, 1990.

Gaos, José. «El sueño de un sueño». Prolija Memoria. Estudios de cultura virreinal, 1:1, (2004): 147-164.

Gates, Eunice Joiner. «Reminiscences of Góngora in the Works of Sor Juana Inés de la Cruz». Publications of the Modern Language Association of America, 54: 4, (1939): 1041-1058.

Góngora, Luis de. Soledades. Robert Jammes (ed.). Madrid: Castalia, 2001.

Góngora, Luis de. Soledades. Antonio Carreira (ed.). Sor Juana Inés de la Cruz. Primero sueño. Antonio Alatorre (ed.). México: Fondo de Cultura Económica, 2009.

Jammes, Robert. La obra poética de don Luis de Góngora y Argote. Madrid: Castalia, 1987.

Jammes, Robert. «Introducción». Luis de Góngora. Soledades. Robert Jammes (ed.). Madrid: Castalia, 2001: 7-157.

López Bueno, Begońa. «De la historia externa de este volumen a la historia interna de la silva». Begoña López Bueno (ed.). La silva. I Encuentro Internacional sobre Poesía del Siglo de Oro. Sevilla: Universidad de Sevilla, Secretariado de Publicaciones, 1991: 5-15.

Méndez Plancarte, Alfonso. «Introducción». Sor Juana Inés de la Cruz, Obras completas, tomo I: Lírica personal. Alfonso Méndez Plancarte (ed.), México: Fondo de Cultura Económica, 1951: VII-LXVIII.

Perelmuter, Rosa. Noche intelectual: la oscuridad idiomática en el "Primero sueño". México: Universidad Nacional Autónoma de México, 1982.

Pérez-Amador adam, Alberto. El precipicio de Faetón: edición y comento de Primero Sueño de Sor Juana Inés de la Cruz. Madrid: Iberoamericana, 2015.

Rivers, Elías. «Soledad de Góngora y Sueño de Sor Juana». Salina: Revista de la Facultat de Lletres de Tarragona, 10, (1996): 69-75.

Roses, Joaquín. «Lecciones de Góngora y disidencias de sor Juana». Edad de Oro, 29, (2010): 289-311. 
Roses, Joaquín. «La descriptio diacrónica en las Soledades». Joaquín Roses (ed.). El universo de Góngora: orígenes, textos y representaciones. Córdoba: Diputación Provincial de Córdoba, 2014: 215-233.

Sánchez Robayna, Andrés. «Algo más sobre Góngora y Sor Juana». Andrés Sánchez Robayna (ed.). Para leer "Primero sueño» de Sor Juana Inés de la Cruz. México: Fondo de Cultura Económica, 1991: 185-200.

SANDoval Caballero, Rosalía. La visualidad en El sueño de Sor Juana Inés de la Cruz: óptica, poesía, pensamiento y teología. Virginia Gil Amate (dir. ${ }^{a}$ ). Rocío Olivares
Zorrilla (codir.a). [Tesis doctoral en proceso de publicación]. Oviedo: Universidad de Oviedo, 2018.

SNYDER, J. Laura. El ojo del observador: Johannes Vermeer, Antoni van Leeuwenhoek y la invención de la mirada. Barcelona: Acantilado, 2017.

StOICHITA, Víctor. El ojo mistico: pintura y visión religiosa en el Siglo de Oro español. Madrid: Alianza, 1996.

Tenorio, Martha Lilia. El gongorismo en Nueva España: ensayo de restitución. México: El Colegio de México, 2013. 